\title{
I am a Child. Hypothesis on Spectator Pedagogy
}

\author{
Esa Kirkkopelto (Helsinki, Finland)
}

In this paper I outline a hypothesis on the spectator pedagogy ${ }^{1}$. The hypothesis bases on my theoretical reflection concerning the question of the scenic work of art in the post-dramatic theatre, partly from my artistic practice, the work I have done with the Helsinki-base live art - group "Other Spaces".

\section{1.}

To begin with the first issue, the possibility of the post-dramatic work of art, I focus on a simple question. If we suppose that all the elements of a scenic composition are equal and deserve their liberty, what happens to the human body when it is considered as just another scenic element among others? And, to put it other way around, what happens to our general understanding of what a compositional or dramaturgical element is, and how it is, if a human being, namely a speaking, acting and plural body, can be considered as one of them?

If we think, as we tend to do nowadays, that a scenic performance transforms, at least momentarily, the bodily existence of a spectator as well, does not this imply that her mode of being is hence brought closer to that of a scenic element? What kind of body I receive as I turn into a scenic element? How do I change? What

\footnotetext{
1 Lecture held at: ACTOR, PERFORMER, CITIZEN. A research meeting organized by the PSi Performance \& Philosophy Working Group in cooperation with the Theatre Academy Helsinki and the Finnish Doctoral Programme for Music, Theatre \& Dance. April 8-9 2011. Theatre Academy, Helsinki.
} 
kind of political implications that transformation may have? Especially: how does it change my status as a political subject, as a citizen?

\section{2.}

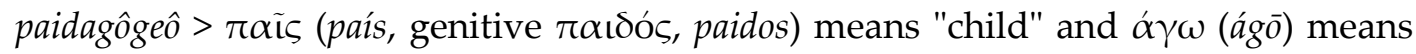
"lead"; so it literally means "to lead the child". It was an office of a slave who accompanied a boy child in his way to school.

If we think about the "pedagogical" effect a scenic performance can have on its spectator, we face a paradox. In fact, the whole term should be understood in a reversed way. What a performance does first and foremost is that it returns its subjects into a more childish position, into a playful state of mind; it leads us, at least momentarily, into childhood again.

The opposition between child and adult is precisely one of those ideological divisions that a scenic performance blurs and puts in question. As Jacques Rancière has recently underlined, this kind of blurring of the borderlines opens a possibility for emancipation. If we think about children and adults, whom are we liberating here? As Rancière suggest, a scenic performance can be judged and criticized from the point of view of a pedagogical authority. Is a performance more mature, more adult than its audience? Is the childhood in theatres a chosen or an imposed position?

One way to approach this question is to think about the theatre education for children, whose traditional task is to teach a child to keep herself away from stage, to sit quiet and still during a performance, regardless of its length. Yet, as civilized adult spectators, we would certainly not be capable of enjoying our spectacles if, somehow, inside our bodies and unconsciously, a child in us did not climb back on the stage and join the performers. Of course, the control of the mimesis is a corner stone of all social behaviour, of which the spectacles are just one. And I am not necessarily claiming here that they should be organized otherwise. I am just wondering what we should think about this "child in us"?

Another obvious example is provided by those contemporary scenic performances where the public is called to participate in performance in one way or another, voluntarily or against its will. In both cases, a spectator experiences, feels, that she has to pass a double barrier, a social one between audience and stage, which removes her in a new position in a commonly shared space, and a more psychic one, which makes her agree to the role, the body or the function the performance suggests to her. Those moments, no matter how annoying or enjoyable they are, turn us into something reduced and simplified as compared with our preceding position as 
more independent and autonomous spectators. The "autonomy" gained here, a possibility to move freely in speak, to speak during the performance, etc., dispossess a spectator from her earlier transcendental position, where she could still regard herself as an inhabitant of two simultaneous worlds, the outer reality and the inner virtual space. The whole situation here gets momentarily virtualized, the play gets generalized, and there is not any more an outer point of view, en exterior determiner. Yet in my mind it would be too much to claim, like Erika Fischer-Lichte seems to do, that this simple turn would "transform" anybody as an individual agency, as a citizen. The relation between performing body and a citizen body should be understood in a more pedagogical way, as a more finite process if you like.

\section{3.}

From the point of view of Art philosophy, we face here a question which has its particular interest and significance in the modern tradition, namely the question of the naivety. For Friedrich Schiller, who reintroduced the concept in his 1796 essay on "Naive" and Sentimental" poetry, the naivety was indeed a quality of all great poetry, no matter if it was written by the Ancients or by the poets of the modern era. The modern poets, just like modern men and women in general, were dominated by an excessive sentimentality and suffered from it. That is why their real challenge, our real challenge, was to regain somehow our naivety. The naivety, less as a genre than as a mode of presentation, was the only cure for the sentimentality, i.e. our urge for interiority, infinity, morality and passion, for all those features of modern subjectivity that threatened to isolate us from reality and from our fellow beings. The naivety, which once was native for the Greeks, is for us a matter of study and exercise. Even though the modern naivety shared with the ancient one some crucial aspects, like overall externality, brilliance, corporeality, playfulness, spontaneity, curiosity and resistance, it had to have a character of its own. Otherwise we would fall back to a simple imitation of the Ancients. As Peter Fenves has defined it, and whose line of analysis I follow here, "sentimentality" meant a developed faculty of the human being to be influenced, to internalize an effect. Whereas the naivety, in both ancient and modern cases, meant a capacity of an individual body of not to get influenced, to persist in the external. The idea of a desirable insensibility, which was easy to understand in the case of the Greeks who grew up in a dangerous affinity with the powers of physis, was no doubt less obvious and harder to hold in the modern times.

In Schiller's theoretical writings, nevertheless, the idea remains consistent. The naivety manifests in a sensible way human being's ethical constitution, the 
given harmony between reason and sensibility. Here lied also its high pedagogical significance for the aesthetic education of the newborn bourgeois citizen. Every time a modern society gives a manifestation of a just social order, there is also something naive, i.e. spontaneously human, in it.

One of the most famous descriptions of this kind of situation is provided by Rousseau who, in his Lettre à d'Alembert, gives us an account of the republic feast organized by citizens of Geneva. According to Rousseau, in this simple dancing party on the central square of the city, the public constituted a splendid spectacle to itself. With this example, Rousseau wanted to reinforce his anti-theatrical judgement he developed in his essay. As Philippe Lacoue-Labarthe has argued, this statement can be read conversely, as a claim for another kind of theatre, a theatre without spectacle. And I think I am not exaggerating by stating that the same anti-theatrical attitude and emansipatory pathos go hand in hand today in various forms of participatory theatre. The aim of the theatre may be less to provide presentations of this or that than actual situation than to carry out a social change - to begin with the group of people that a performance has gathered together. Yet, as I want to stress here, this move presumes still another transformation that takes place at the level of the bodily existence of both performers and spectators. Every time something happens on the street, a party, a manifestation, a riot, the people do not behave anymore like bourgeois autonomous citizens who accomplish their civil responsibilities. Their citizen body has gone through a transformation similar to performance contexts. In both cases, we are not carrying anymore the body of a bourgeois citizen, but our mode of being has become somehow reduced, simplified. In Schillerian terms: it has become more naive.

That is why it seems to me possible to reverse the perspective and pose the question of the spectator pedagogy.

\section{4.}

Performing arts manifests our right to become another, our pleasure to become another and our right to the pleasure as well. Each performance does it in its own way, providing us with different kinds of bodies. The question remains whether we can describe and understand the mode of being of the transformed body that enjoys in such situations. Since Rousseau, Diderot and Schiller, the political meaning of scenic performances has not been in its way to accomplish a given social "function" but manifest and lay bare, replay the conditions of our social existence beyond and before the given aesthetic distributions. In Schillerian terms, this means that we have to learn to overcome the sentimental, to not get influenced! Not to become 
indifferent, but just different. Our mimetic capacity has to be simultaneously liberated and protected, purified. That is what a scenic performance can certainly do. But what kind of social or political relevance are we ready to give to this transformation? It does not suffice to praise "the transformative power of performance" like Erika Fischer-Lichte suggests, if we do not regard what takes place beyond and around those performances, in the societies; if we do not take care of the bodies transformed and provide them with a survival. Otherwise we are just fulfilling "functions".

According to the sceptical and traditional counter-argument (often used also in the debates on cultural policy), the momentary mutual agreement or harmony that a scenic performance produces among its participants has no "real" political or social significance, since it is conditioned by the exclusion of the outer "real" world and has no correspondence within it. In the present context, we can claim the contrary. As people encounter each other within a performance, what is created is an autonomous situation which is not based anymore on the point of view of an economically and morally autonomous subject and his or her supposed "rights" as a consumer-spectator. What takes place is the redefinition of social autonomy beyond its given distributions.

Philippe van Parijs, a theoretician of "political ecology", much influenced by André Gorz, has argued that the traditional political economy has got stuck on a two dimensional perspective suspended between the liberal market economy and the socialist state policy. In addition, we should take into account the third level of social economical activity that he calls an "autonomous sphere":

The political space of industrial society can be depicted as a line drawn from the extreme right of the all-encompassing market to the extreme left of the all-encompassing state. The political space of the post-industrial society, by contrast, should be depicted as a triangle whose bas is formed by the line just described, and whose third angle corresponds to what should be a fully "autonomous" society. (Van Parijs, 2009, p. 2)

The expression 'autonomous sphere' is here used in a purely subtractive sense, to refer to one category of productive activities broadly conceived, that is, on subset of contributions to the creation of goods and services useful to oneself or to others. This subset comprises all the productive activities whose products are neither sold on the market nor commissioned by a public authority. It is in this sphere that we move, for example, when we mow the lawn or give birth, when we organize a street party or correct a Wikipedia entry, when we look for an inexpensive retirement home for an elderly neighbour or stick up posters in a tube station to advocate basic income, when we corner a vandal in the subway or teach our children how to carve a pumpkin. (Van Parijs, 2009, p. 2)

This should not be seen as a communitarian utopia. The communism that Parijs describes here is restricted. The political ecologists like Parijs do not think that a 
86 I Esa Kirkkopelto

society could work without markets or without a state rule. The whole issue is to face the irreducibility of the "autonomous sphere" as a political sphere.

\section{5.}

My suggestion: the autonomy in the arts, the autonomy of the arts, the condition of existence of the arts and the artists in the modernist and post-modernist societies, could be understood and defended as referring to this kind of social existence, whose rights today should be politically acknowledged. For instance, as many argue, by procuring to each citizen a "basic income".

Why is it so important?

For instance, as the political ecologists argue, it is the sphere or the class that is most eager and ready to move into a more sustainable society, since it has the least to loose in the uncomfortable changes the ecological catastrophe we live through imposes on the societies. To put it simply, whatever happens we can be sure that on the everyday level the life goes on, some way or another. That is also why it is a level of survival. This survival does only concern the satisfaction of our basic needs but also, as Jean-Claude Milner has recently argued, our very possibility as political beings, as speaking multiple bodies. A surviving body is not the one of the bourgeois subject.

What scenic performances could show in these circumstances is what could be won in these changes, like mutual freedom, equality without identity, and more far reaching social justice. The scenic performances and performers would not need to prove their social relevance by referring to an outer "reality" defined by the financial powers. Instead, we could think and claim that in each case these performances are already "out there": they take place in the society as a part of its autonomous sphere. The program of the "aesthetic education" could hence be understood today as "spectator pedagogy", as a collective public exercise that makes us conscious of the political aspects of what we each one of us already can do and know, of the "everyday life". The scenic performances would prepare us in so many ways to live a simpler and more sustainable life, the mode of life within the reach of every one on this planet.

\section{References}

Van Parijs, Ph. (2009). Political Ecology: From Autonomous Sphere to Basic Income. Basic Income Studies, Vol. 4, Issue 2 (December). 
Esa Kirkkopelto (Helsinki, Finland)

\title{
I am a Child. Hypothesis on Spectator Pedagogy
}

\begin{abstract}
The paper consists of series of suggestions and historical references on the basis of which it would become possible to think and practice "spectator pedagogy" in performing arts. Contemporary performance practices can claim for new kind of political relevance by focusing on the way spectator's corporeal experience changes during and through theatrical situation. Naive body produced by a performance is also most susceptible for thoroughgoing political and ecological change. This is the first outline by its author on this topic.
\end{abstract}

Keywords. Children' philosophy, citizenship, autonomy, meta-ethics with practical consequences, performing arts

Author. Docteur en philosophie, Université Marc Bloch, Strasbourg. Former playwright and director. Professor of Artistic Research, Theatre Academy Helsinki. Author of Le Théatre de l'expérience (Presses de l'Université Paris Sorbonne, 2008). Convenor of “Other Spaces" live art group. Research interests: deconstruction, actor training, scenic composition, political aspects of performing arts

Contact Address. Theatre Academy Helsinki, P.O. Box 163, 00531 Helsinki, Finland.

Citations. Reference this paper as: Kirkkopelto, E. (2011). I am a Child. Hypothesis on Spectator Pedagogy. Ethics in Progress Quarterly, Volume 2, Issue 2, pp. 81-87, available online at ethicsinprogress.org. 